\title{
Reactive Resins Filled with Microparticles Based on Iron Powder
}

Petr Valášek

Department of Material Science and Manufacturing Technology, Faculty of Engineering, Czech University of Life Sciences Prague. Kamýcká 129, 165 21, Prague. Czech Republic. E-mail: valasekp@tf.czu.cz

Hard inorganics microparticles are added to the composite systems due to optimization of some mechanical properties among which is possible to rank hardness and resistance to abrasive wear. Advantage of interaction of metal powders with polymers is also their ferromagnetism which changes physical properties of resulting composite systems. This paper is focused on evaluation of mechanical properties of epoxy resin filled with microparticles on the basis of iron powder $(20.6 \mu \mathrm{m})$, mainly on resistance to abrasive wear, hardness and on adhesive and cohesive characteristics. The experiment evaluates composite systems prepared without using controlled semi-layers and without using a vacuum technology. Such technology was chosen with regard to practise. It is possible to consider the adhesive and cohesive characteristics as key properties determining possible application areas of filled reactoplastics. For evaluation of fracture areas was used electronic microscopy. The experiment confirmed significant increase of resistance to abrasive wear with increasing concentration of iron powder. This property can be utilized in widening the application areas of reactoplastics resins, i.e. creating the new resistant layers.

Keywords: Abrasive wear, epoxy resin, hardness, tensile strength.

\section{Acknowledgement}

The results were supported by the grant IGA TF 2015 (31140/1312/3107).

\section{References}

[1] MÜLLER, M., VALÁŠEK, P. (2012). Abrasive wear effect on Polyethylene, Polyamide 6 and polymeric particle composites. In: Manufacturing Technology, 12, pp. 55 - 59.

[2] VALÁŠEK, P., MÜLLER, M. (2013). Polymeric composite based on glass powder - Usage possibilities in agrocomplex. In: Scientia Agriculturae Bohemica, No. 2, pp. 107 - 112.

[3] VALÁŠEK, P., MÜLLER, M. (2013). Polyurethane resins filled with inorganic waste particles. In: Manufacturing Technology, Vol. 13, No. 2, pp. $241-247$.

[4] RUGGIERO, A., et al. (2015). Friction and wear behaviors of Al/Epoxy Composites during Reciprocating Sliding tests. In: Manufacturing Technology, Vol. 15, No. 4, pp. $684-689$.

[5] SATAPATHY, B.K., BIJWE, J. (2002). Analysis of simultaneous influence of operating variables on abrasive wear of phenolic composites. In: Wear, 253, pp. $787-794$.

[6] XUE QUNJI, WANG QUIHA. (1997). Wear mechanisms of polyetheretherketone composites filled with various kinds of SiC. In: Wear, 213, pp. $54-58$.

[7] YU, Y.H. et al. (2014). Preparation, morphological, and microwave absorbing properties of spongy iron powders/epoxy composites. In: Journal of the Taiwan Institute of Chemical Engineers, Vol. 45, No. 2, pp. 674 - 680.

[8] CHOI, H. et al. (2008). Fracture behavior of carbon/epoxy laminated composite reinforced by iron powder. In: Korean Journal of Chemical Engineering, Vol. 25, No. 5, pp. 1208 - 1211.

[9] NOVÁK, M. (2012). Surfaces with high precision of roughness after grinding. In: Manufacturing Technology, 12, pp. $66-70$.

[10] MÜLLER, M. (2014). Influence of adhesives storing temperature on adhesive bond strength. In: Manufacturing Technology, Vol. 14, No. 1, pp. $71-75$.

[11] ŤAVODOÁ, M. (2013). The surface quality of materials after cutting by abrasive water jet evaluated by selected methods. In: Manufacturing Technology, Vol. 13, No. 2, pp. 236 - 241.

[12] KAHRAMANA, R., MEHMET SUNARB, BEKIR YILBAS. (2008). Influence of adhesive thickness and filler content on the mechanical performance of aluminum single-lap joints bonded with aluminum powder filled epoxy adhesive. In: Materials Science Forum, Vol. 205, pp. 183 - 189.

[13] KILIK, R., DAVIES, R. (1989). Mechanical properties of adhesive filled with metal powders. In: International Journal of Adhesion and Adhesives, Vol. 9, No. 4 pp. $224-228$.

[14] KAVAK, N., ALTAN, E. (2012). Influence of filler amount and content on the mechanical performance of joints bonded with metal powder filled adhesive. In: 15th International Conference on Advances in Materials and Processing Technologies, Wollongong, NSW; Australia, Vol. 773-774, pp. 226 - 233. 